\title{
IT Tools Used to Reduce the VAT Loophole- JPK_VAT, STIR, Split Payment Mechanism
}

\author{
Beata Hoza ${ }^{1}$, Adam Żabka ${ }^{2}$ \\ ${ }^{1}$ Department of Finance and Information Technologies, Bielsko-Biała School of Finance and Law, Poland \\ ${ }^{2}$ Department of Finance and Information Technologies, Bielsko-Biała School of Finance and Law, Poland
}

\begin{abstract}
Tax leakage is a challenge for fiscal organs in many countries which make use of the Value Added Tax (VAT) in their tax system. It is a widespread phenomenon also in Poland. In order to reduce the so called tax loopholes or gaps it is necessary to implement changes in the legal system which will allow to conduct data analysis through information technologies using control algorithms. When it comes to Poland, such analyses can be conducted thanks to the following tools: VAT Standard Audit File for Tax (SAF-T) - in Poland referred to as JPK_VAT file, STIR the teleinformation system of KIR - the key entity of the Polish payment infrastructure, and the VAT split payment mechanism. The aim of the paper is to present the estimated value of the VAT loophole in Poland and other EU member states in the period 2015-2016, and to point to steps which aim at reducing the size of the gap through application of IT tools.
\end{abstract}

Key words - Value Added Tax, tax on goods and services, VAT loophole, JPK_VAT file, the split payment mechanism

\section{INTRODUCTION}

Although the tax on goods and services, being a Polish variant of the Value Added Tax (VAT), is the basic source of state budget revenues, its fiscal efficiency is being considerably hindered. In the view of the Polish state organs 'widely understood fiscal crime especially with respect to the Value Added Tax and Excise Tax, generates massive losses for the state budget and undermines economic security of the country' (MSW, 2015). The tax on goods and services (VAT) is a consumption tax placed on a product or service whenever value is added at each stage of the supply chain, from production to the point of sale. Such construction of the tax on one hand accelerates its collection, but on the other hand may become an invitation to abuse. Taxes perform fiscal role (Owsiak, 2005), (Rusikowski and Kosikowski, 2006), (Wójtowicz, 2002), (Kulicki and Sokól, 1996), (Famulska, 2007), therefore they should be an effective source of revenues for public authorities, which means that the state should reach for such an object of

ASEJ - Scientific Journal of Bielsko-Biala School of

Finance and Law

Volume 22, No 3 (2018), 5 pages

DOI: $10.5604 / 01.3001 .0012 .7775$

Received 04 September 2018; Accepted 15 September 2018 taxation (of things, occurrences) which would provide sufficient resources for the performance of central and local administration tasks (Ciupek, Famulska and Walasik, 2006). However, the extent of abuse as regards the tax on goods and services generates considerable losses in budget revenues, violates the fair taxation principle (Głuchowski and Patyki, 2011) and disturbs market competitiveness. New legal regulations are hoped to enforce certain limitations to the extent of malpractices, and some existing legal solutions which make these malpractices possible are going to be liquidated. Thanks to the new legislation it will be possible to implement such legal instruments which will encourage taxpayers to conduct business activity in a way which is compatible with the law.

\section{VALUE ADDED TAX LOOPHOLES}

The Polish legal system has not yet defined the term 'tax loophole' or 'tax gap' which was coined by the OECD and developed for the purposes of reporting, conducting research and comparative analyses. The 'loophole' is defined as the difference between the amount of tax due and the amount which was actually paid into the state budget (PWC, 2013, p.3).

Unwillingness to fulfil tax obligations is a common phenomenon known since the beginning of taxation. Taxpayers treat their tax obligation as a certain limitation of their rights and freedoms so they search for ways to avoid or just to reduce this burden. The dilemmas so characteristic for the whole history of taxation are still valid in modern times, however now, with even more tax avoidance opportunities, tax fraud is easier to commit than ever before. This situation is caused by globalization processes accompanied by a tendency to break down any existing barriers in order to guarantee free movement of people and capital.

The leakage of the tax on goods and services is a universal problem of fiscal organs of many countries where the Value Added Tax is in use. Therefore, it may be assumed that the loophole in the revenues not only is a sign of weakness of fiscal organs but also, to a certain extent, the consequence of the very

Regular research paper: Published 20 October 2018 Corresponding author's e-mail: hoza@op.pl ; azabka@wsfip.edu.pl Copyright (C) 2018 This is an open access article distributed under the Creative Commons Attribution CC-BY-NC 4.0 License. 
construction of the tax, which is vulnerable to malpractice and unable to defend itself.

According to the statistics published by the European Commission, the EU member states lost 150 billion EURO of VAT revenues in 2016 alone. The VAT loop ranged from $35,9 \%$ of unpaid VAT in Romania, to $0,85 \%$ in Luxemburg (in Poland 24,5\%). When expressed in absolute amounts, the biggest loophole was observed in Italy ( 35.1 billion EURO), whereas in Poland in 2015 the loophole was estimated at the level of 9.8 billion EURO (CASE, 2018) (Chart 1).

\section{CHART 1. ESTIMATES OF VAT LOOPHOLES IN EU-27 IN 2015 AND 2016 (AS \% OF POTENTIAL REVENUES)}

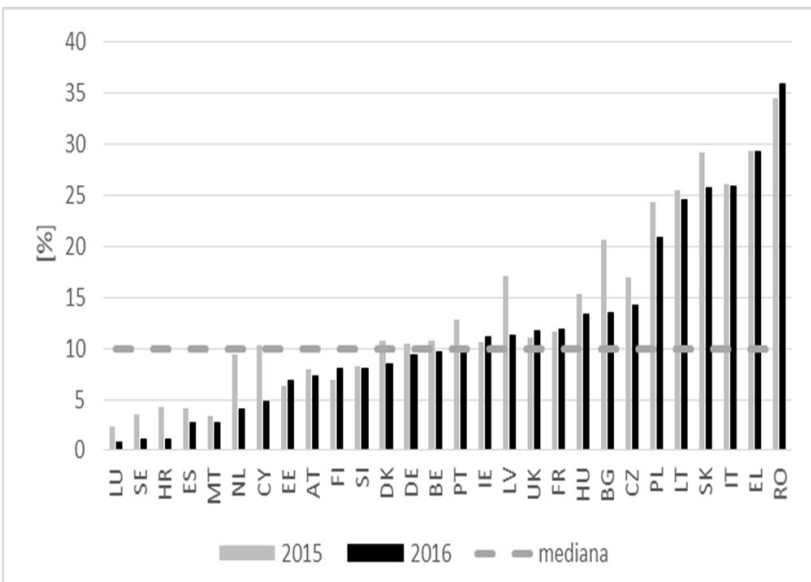

Source: CASE, Study and Reports on the Gap in the EU-28 Member States: 2018, Final Report, TAXUD/2015/CC/131

Tax loophole is just an estimated value arrived at through various statistical data, including estimates coming from the grey economy, thus its value must be interpreted with caution. A much closer attention must be paid to the changes in time. Data gathered in Chart 2 show an alarming trend upwards of the VAT loophole in Poland. With the exception of the period 2005-2008 the gap remained above the level of $15 \%$. It proves insufficient efficiency of the Polish fiscal system and the need to implement new solutions which would reduce the scope of tax fraud (NIK, 2016).

One solution that may be effective in reducing the scope of grey economy is appropriate legislation which will allow to use such information technologies which facilitate flow of information and conduct data analyses based on control algorithms.

When it comes to Poland, the following IT tools are currently being implemented:

- Standard Audit File for Tax (in Poland called JPK_VAT file) - under gradual implementation process (mandatory),

- STIR teleinformation system,

VAT split payment mechanism (voluntary).

\section{CHART 2. ESTIMATES OF VAT LOOPHOLE IN POLAND IN THE PERIOD 2000-2016}

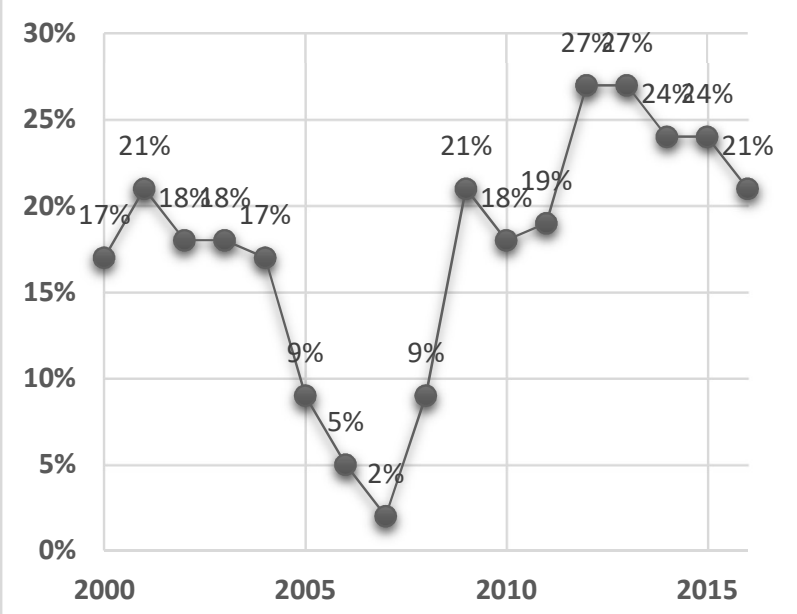

Source: Own work based on: CASE, Study to quantify and analyse the VAT Gap in the EU-27 Member States 2013. Final Report, TAXUD/2012/DE/316, Study and Reports on the Gap in the EU-28 Member States:2018, Final Report, TAXUD/2015/CC/131

\section{JPK_VAT FILE - POLISH VERSION OF STANDARD AUDIT FILE FOR TAX}

Standard Audit File for Tax is a database made of the IT system of an entrepreneur. The database stores information on business operations for a given period in a format and layout which makes the processing of data fast and easy. The data is transferred by means of a template prepared by the Ministry of Finance (in the XML form used as a standard in electronic communication). Standard Audit File for Tax (SAF-T) had been developed in OECD in 2005 and was used for the first time in 2008 in Portugal where it brought the desired effects. The concept was soon adopted in other countries such as: Germany, Great Britain, Denmark, Holland, Sweden and Slovenia.

The Polish version of Standard Audit File for Tax (JPK VAT file) consists of 7 structures: accounting books (JPK_KR), bank statements (JPK_WB), warehouses (JPK_MAG), records of VAT purchase and sales (JPK_VAT), VAT invoices (JPK_FA), revenue and expense ledger (JPK PKPIR) and revenue account (JPK EWP). The term JPK refers to all data which compulsorily or on demand must be handed over to the Inland Revenue Office. One category of data which must be sent to the Inland Revenue Office in JPK format is all VAT related data - JPK_VAT. With respect to monthly preparation of JPK_VAT, it is obligatory for large enterprises starting 1 July $201 \overline{6}$, for small and medium sized enterprises starting 1 January 2017, and for micro enterprises starting 1 January 2018 (Table 1).

JPK VAT file contains the register of VAT sales and purchase ordered in a logical structure. For instance, VAT sales register includes the following information (for each transaction): date of sales, date of issuance, number of the document, name of the buyer, address of the buyer, net amount and the amounts of the tax due broken into particular tax rates.

The structure of VAT purchase register is based on a similar 
principle. At the same time, the JPK_VAT file features all data needed for preparation of a tax return and summary information, and constitutes the basis for verification of accuracy of tax deductions and confirmation that the invoices were issued by an empowered entity (an active VAT taxpayer).

TABLE 1. STAGES OF JPK_VAT FILE IMPLEMENTATION

\begin{tabular}{|c|c|c|c|c|}
\hline $\begin{array}{c}\text { JPK } \\
\text { STRUCTUR } \\
\text { E }\end{array}$ & $\begin{array}{c}\text { LARGE } \\
\text { ENTERPRIS } \\
\text { ES }\end{array}$ & $\begin{array}{c}\text { MEDIUM } \\
\text { SIZED } \\
\text { ENTERPRIS } \\
\text { ES }\end{array}$ & $\begin{array}{c}\text { SMALL } \\
\text { ENTERPRIS } \\
\text { ES }\end{array}$ & $\begin{array}{c}\text { MICRO } \\
\text { ENTERPRIS } \\
\text { ES }\end{array}$ \\
\hline JPK_VAT & 1 JULY 2016 & $\begin{array}{c}1 \text { JANUARY } \\
2017\end{array}$ & $\begin{array}{c}1 \text { JANUARY } \\
2017\end{array}$ & $\begin{array}{c}1 \text { JANUARY } \\
2018\end{array}$ \\
\hline \multicolumn{3}{|c|}{ Source: own work based on article 6 point 2 of the Act of 13 May 2016} \\
\hline
\end{tabular}
amending the Tax Ordinance

The success of the Standard JPK file depends on its universality. The number of entities who were obliged to submit JPK_VAT but failed to do so is consistently decreasing- from $5,4 \%$ in January 2018 to 2,9\% in June 2018 (Chart 3).

\section{CHART 3. NUMBER OF ENTITIES FAILING TO SUBMIT JPK_VAT FILE} $(01-06 / 2018)$

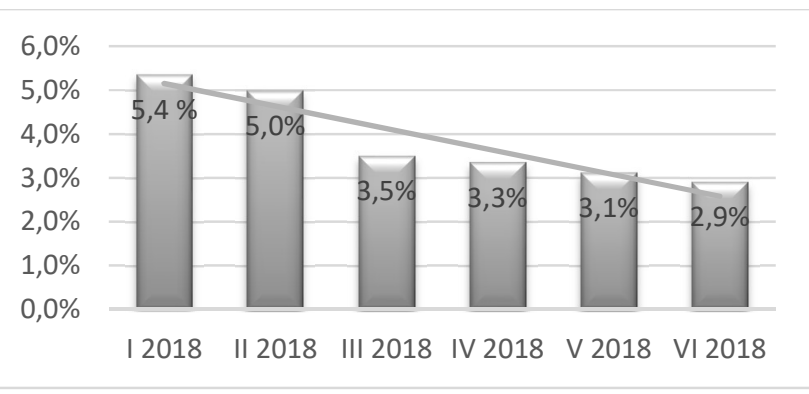

Source: Analysis JPK_VAT and STIR. www.mf.gov.pl

In the first half of 2018 the system identified and called into question 155.443 invoices, issued by 55.780 entities not registered as taxpayers of VAT. The amount of VAT due on these invoices amounted to over 260 million PLN (Mf.gov.pl, 2018).

The most frequent inconsistencies detected in the JPK_VAT files refer to:

- divergences in the submitted JPK_VAT files and the tax returns filed for the same period,

- divergences with respect to transactions shown in the JPK VAT files,

- cases of including in JPK_VAT files VAT invoices purchased by entities without the status of an active VAT taxpayer (Finanse.mf.gov.pl, 2018).

JPK_VAT system has automated audit activities. Thanks to the system the National Revenue Administration can react quickly to any inconsistencies and attempts at tax fraud. Special algorithms used during the analysis of JPK_VAT files immediately single out fictitious transactions made by dummy corporations.
IV. STIR - A TELEINFORMATION SYSTEM OF KIR (THE KEY ENTITY OF THE POLISH PAYMENT SYSTEM INFRASTRUCTURE)

STIR is a fiscal administration tool introduced to the legal system by the Act of 24 November 2017. The tool aims at preventing the organized crime groups from using the financial sector for fiscal fraud especially in the so called carousel fraud. 'Carousel' refers to such money transfers on bank accounts which are intended, in the final moment, at obtaining undue VAT reimbursement. Based on the data accumulated in the STIR software, the computer system analyses the risk of fiscal fraud occurrence. Pursuant to the above mentioned Act, the head of the National Revenue Administration gets access to information on:

- accounts of eligible counterparties (i.e. other than accounts of natural persons used for private purposes) - as of 13 March 2018,

- all transactions of eligible counterparties made through commercial bank accounts or accounts of the Cooperative Savings and Credit Unions (SKOK) - as of 1 July 2018.

The STIR Act also stipulates who can become an eligible counterparty:

- natural person being an entrepreneur;

- natural person being self-employed;

- legal person;

- non-corporate entities having legal capacity.

STIR is intended to maintain tight supervision over bank operations made by business entities. All entities are under surveillance irrespective of the fact whether non-compliance procedures have been initiated for them or not. The system, which conducts risk analysis, is based on software algorithms the data is sent and analyzed automatically by the IT system in order to detect the risk of fiscal fraud. Should a threat be detected, the head of the National Revenue Administration (KAS) is entitled to suspend the account of the identified eligible counterparty. If the estimated value of the tax obligation exceeds 10.000 EURO, the suspension on the account may be prolonged to the period of three months. The STIR Act is not binding for accounts of natural persons which are used for private settlements. Thanks to the analysis provided by the STIR software, it is possible to establish which business entities are fictitious and exist only for the purposes of VAT carousels. The demands of the head of KAS concerning the suspension of accounts of eligible counterparties are also processed and sent electronically which assures speedy and appropriate reaction.

In the period between March 2018 and end of September 2018 (Mf.gov.pl, 2018) the system analyzed more than 5 billion bank transactions and singled out more than 26.000 high risk taxpayers; 12 bank accounts belonging to 8 entities were suspended, the accumulated resources on these bank accounts amounted to 3 million PLN.

It should be observed, that the legislation concerning the STIR system gives fiscal organs discretionary powers which results from unspecified and inconsistent criteria, generally referred to as 'risk algorithm'. Such provision makes it possible for each business entity to become a subject of scrutiny of relevant financial and fiscal institutions. It must be emphasized, 
however, that the risk analysis is based on transactional data which helps to tighten the fiscal system in Poland and creates a good environment for efficient battle with the carousel crime.

\section{VAT SPLIT PAYMENT}

The VAT split payment mechanism aims at tightening of the fiscal system and increasing the security of the business turnover (La Grutta, 2015). The tool has been introduced in Poland on voluntary basis, as an extension to the Polish VAT law, starting 1 July 2018. Split payment mechanism is not commonly used in the European Union countries. In fact it is only operational in three countries: in Italy, where split payment is used in settling transactions with public entities; in the Czech Republic, where it is voluntary and taxpayers may use it for protection against the joint and several liability principle; and in Romania, where split payment constitutes a kind of sanctions connected with overdue VAT payments into the state budget.

The VAT split payment mechanism completely changes the way in which the tax on goods and services is collected. The clients of the entity will perform two electronic payments: one payment amounting to the value of the acquired goods/received services (i.e. the net amount without VAT) into the usual bank account and one payment amounting to the VAT into a specially created VAT account which is under constant supervision exercised by a fiscal organ.

The split payment operation may be performed automatically by a special settlement system which divides the payment and transfers it into two separate accounts; or manually by the taxpayers who make two separate transfers into two separate accounts. Tax payers should open the VAT bank account with a commercial bank. Alternatively, they may open a VAT account with the state treasury, in which case the account is managed by the central bank. It should be emphasized that the VAT split payment may be used only for transactions between two taxpayers, the B2B (business-to-business) model. The mechanism cannot be applied in B2C (business-to-consumer) environment.

The split payment mechanism is a preventive tool which can eliminate or at least considerably reduce the risk of imposing on a taxpayer the liability for VAT which should have been settled in earlier stages of the business turnover. In July and August 2018, the split payment mechanism was used by more than 120.000 Polish businesses in 2.4 million transactions worth 40 billion PLN. This means that more than $7 \%$ of all entitled entities used this solution in transactions which constituted $1,5 \%$ of all transactions made in this period between VAT payers. As regards the value of transactions, the value of split payments amounted to $5 \%$ of the total value of transactions in this period (Gazeta Prawna, 2018) (Chart 4).

Poland belongs to the small group of countries which have implemented the VAT split payment mechanism. The split payment variant introduced in Poland is friendly for the taxpayer and rather easy to execute: the amount which arrives at the seller is already reduced by $23 \%$.
CHART 4. PRESENCE OF SPLIT PAYMENT IN THE FIRST TWO MONTHS OF APPLICATION (07-08/2018)

Value of transactions

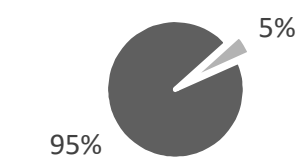

- bank transfer - split payment

Number of entities

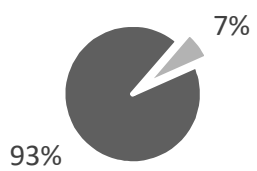

- bank transfer = split payment

Number of transactions

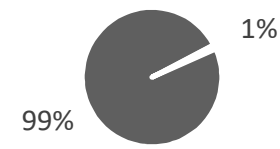

- bank transfer $\quad$ split payment

Source: own work based on Czy split payment to sukces?, the Ministry of Finance

The application of the VAT split payment mechanism will impact businesses with varying degrees. Problems with liquidity may occur in case of entities who perform activities taxable at $8 \%$ VAT rate and purchase goods and services taxed at $23 \%$ VAT rate. The most affected will be the agri-food industry or the construction industry. It should be highlighted however, that the decision concerning making the payment in the split payment formula is made by the buyer not the seller. According to the Ministry of Finance, the VAT split payment mechanism is one of the final stages of tightening the tax system.

\section{CONCLUSIONS}

The teleinformation tools described above are indispensable elements in the process of tightening the tax system. To be effective however, they require a comprehensive approach so that all individual constituents could complement one another and work in harmony. Definitely, the most effective will be the tools imposed mandatorily.

The advantage of the JPK_VAT file is that it allows for efficient analysis of a large volume of data. The key asset of the 
system is the speed of elimination of errors which helps to reduce the number of necessary tax audits in companies and shortens the time of these audits. Selecting entities for audit is based on risk analysis, and as the result actual audits can be performed only in companies where the risk of irregularities is really high. Network approach to tax and bank related information about business activity of entities used in the STIR system has shown considerable potential but is still in need of further development. Fusion of the STIR data with data from JPK_VAT file will offer vast possibilities of trade transactions analysis and payment analysis. In the presented package of IT tools aimed to reduce the VAT loophole, the least effective is probably the split payment mechanism as it is used on voluntary basis.

Only a mandatory system embracing most sectors but especially: fuel trading, steel and scrap material trading, electronics and construction services, would bring considerable results and would contribute to the reduction in the VAT loophole.

\section{REFERENCES}

Biuletyn Informacji Publicznej MSWiA. (2018). Biuletyn Informacji Publicznej MSWiA. [online] Available at: http://www.bip.mswia.gov.pl/.

Chądzyński, M. (2018). Czy split payment to sukces? Ministerstwo Finansów ujawnia pierwsze dane. Gazeta Prawna.

Ciupek, B., Famulska, T. and Walasik, A. (2006). Finanse publiczne. Warszawa: Stowarzyszenie Księgowych w Polsce, p.7.

Edgp.gazetaprawna.pl. (2018). e-Dziennik Gazeta Prawna - e-wydanie - prawo, podatki, biznes, finanse. [online] Available at: https://edgp.gazetaprawna.pl/.

Famulska T. (2007). Funkcje i zasady podatkowe-wybrane problemy, w: Juja T., Kotliska J. (red.): Stan i kierunki rozwoju finansów publicznych, Poznań: Akademia Ekonomiczna, p.7.

Głuchowski, J. and Patyki, J. (2011). Zarys polskiego prawa podatkowego. Warszawa: LexisNexis, p.16.

Informacja o wynikach kontroli Przeciwdziałanie wprowadzaniu do obrotu gospodarczego faktur dokumentujących czynności fikcyjne. (2016). Warszawa: NIK, p.35.

Kulicki J., Sokół P.(1996). Podatki i prawo podatkowe, Warszawa: PWE, p. 29.

La Grutta S. (2015) Split payment Mechanism for Public Bodies, International VAT Monitor, (Volume 26), No. 2.

Mf.gov.pl. (2018). [online] Available at: https://www.mf.gov.pl/.

Owsiak, S. (2005). Finanse publiczne. Warszawa: PWN, p.128.

PwC. (2018). PwC: audyt, doradztwo podatkowe, prawne i biznesowe. [online] Available at: https://www.pwc.pl/, p.3.

Raport o stanie bezpieczeństwa w Polsce w 2014 roku. (2015). Warszawa: MSW.

Rusikowski, E. and Kosikowski, C. (2006). Finanse publiczne $i$ prawo finansowe. Warszawa: ABC Dom Wydawniczy, p.25.

Study and Reports on the Gap in the EU-28 Member States:2018, Final Report. (2018). CASE, p.16.

Study to quantify and analyse the VAT Gap in the EU-27 Member States. Final Report. (2013). 1) CASE, p. 123.

Wójtowicz W. (red), (2002). Zarys finansów publicznych. Warszawa: Dom Wydawniczy ABC, p. 130. 